\title{
PERBANDINGAN METODE LATIHAN CONE DAN REACTION BALL TERHADAP KELINCAHAN ATLET PUTERI KLUB BOLA VOLI FORTIUS UNIVERSITAS NEGERI JAKARTA
}

\author{
Dwita Febriyanti \\ Rina Ambar Dewanti dan Bambang Sujiono
}

\begin{abstract}
ABSTRAK. Penelitian ini bertujuan untuk mengetahui pengaruh metode latihan cone terhadap kelincahan, mengetahui pengaruh metode latihan reaction ball terhadap kelincahan, dan mengetahui perbandingan metode latihan cone dan reaction ball terhadap kelincahan Atlet puteri klub bola voli Fortius Universitas Negeri Jakarta.

Penelitian ini dilakukan dari tanggal 6 maret sampai dengan 22 april 2017 sudah termasuk dengan tes awal dan tes akhir. Total pertemuan latihan berjumlah 16 kali pertemuan latihan. Metode penelitian yang digunakan dalam penelitian ini adalah metode eksperimen. Populasi yang digunakan dalam penelitian ini adalah atlet klub bola voli Fortius Universitas negeri Jakarta yang terdiri dari 45 orang atlet putera dan 27 orang atlet puteri. Teknik yang digunakan dalam pengambilan sampel adalah purposive sampling sehingga sampel yang digunakan berjumlah 20 orang atlet puteri yang memenuhi kriteria.

Instrumen penelitian yang digunakan adalah dengan mengukur kelincahan Atlet puteri klub bola voli Fortius Universitas Negeri Jakarta menggunakan T-Run Agility Test. Teknik analisis data uji-t dengan menghitung nilai t-hitung dibanding dengan t-tabel pada taraf kepercayaan $\alpha=0,05$.

1. Data hasil tes awal dan tes akhir kelincahan pada metode latihan cone dengan uji-t pada taraf kepercayaan $\alpha=0,05$. Hasil dari metode latihan ini t-hitung 10,888 dan t-tabel 2,262. Sehingga metode latihan ini dapat meningkatkan kelincahan.

2. Data hasil tes awal dan tes akhir kelincahan pada metode latihan reaction ball dengan uji-t pada taraf kepercayaan $\alpha=0,05$. Hasil dari metode latihan ini t-hitung 9,647 dan t-tabel 2,262. Sehingga metode latihan ini dapat meningkatkan kelincahan.

3. Data yang diperoleh dari tes akhir di uji dengan uji-t pada taraf kepercayaan $\alpha=0,05$. Hasil tes akhir kedua kelompok adalah t-hitung 2,812 dan nilai t0tabel dengan derajat kebebasan $(\mathrm{db} b=$ $\mathrm{n}+\mathrm{n}-2)=18$ dan taraf kepercayaan $\alpha=2,101$. Dengan demikian t-hitung tes akhir metode latihan cone dan reaction ball dari nilai t-tabel yaitu t-hitung 2,812 > t-tabel 2,101, oleh karena itu Ho ditolak yang berarti ada perbedaanyang signifikan antara melakukan metode latihan metode latihan cone dan reaction ball.

Kesimpulan akhir yang diperoleh melalui penelitian ini adalah metode latihan cone lebih efektif daripada metode latihan reaction ball terhadap kelincahan atlet puteri klub bola voli Fortius Universitas Negeri Jakarta.
\end{abstract}

\section{Kata Kunci: Metode Latihan, Cone, Reaction Ball, Kelincahan, Bola Voli}

\section{PENDAHULUAN}

Pembinaan dan pengembangan

keolahragaan secara nasional perlu terus

dikembangkan dan dilaksanakan dalam meningkatan prestasi olahraga di Indonesia.
Pembinaan dan pengembangan menjadi tanggung jawab dan peranan dari berbagai pihak agar berjalan dengan baik. Pembinaan dapat ditingkatkan dari mulai daerah, provinsi hingga tingkat Nasional 
Prestasi dapat dicapai oleh setiap orang yang memiliki bakat, minat kemampuan, dan potensi, oleh karena itu prestasi didapatkan dari pembinaan dan pengembangan olahraga. $\mathrm{Di}$ Indonesia pengembangan dan pembinaan olahraga dapat diperoleh dari perkumpulanperkumpulan yang terdapat disetiap daerah yang disebut klub.

Pada saat ini pembinaan tingkat klub dalam menjalankan program masih belum jelas. Hal ini disebabkan oleh beberapa faktor seperti ketidak tetapan jadwal pertandingan bola voli yang dilaksanakan, kualitas pelatih, sarana dan prasarana, dan masih banyak faktor lainnya. Program latihan yang tidak jelas ini juga berdampak dengan kondisi atlet yaitu kondisi secara fisiologis maupun psikologis atlet.

Upaya meningkatkan kemampuan atlet komponen latihan yang diberikan harus bertahap meliputi latihan teknik, fisik, dan taktik. Latihan ini disusun dan diatur dalam program latihan yang dapat menentukan peak performance atlet. Dalam peningkatan keterampilan atlet harus melalui beberapa proses dikarenakan banyaknya komponen teknik yaitu spike, block, defense, dan service. Setiap komponen teknik membutuhkan dukungan dari kondisi fisik yang baik untuk setiap atlet. ada beberapa komponen fisik yang mempengaruhi peak performance atlet antara lain: kekuatan, kecepatan, daya tahan, kelentukan, kelincahan, reaksi, dan keseimbangan.

Berdasarkan karakteristik tersebut maka atlet bola voli harus melatih komponen itu, tentunya melalui proses latihan, sedangkan tujuan latihan dapat membantu atlet meningkatkan keterampilan dan potensi yang dimiliki atlet semaksimal mungkin.

Dari semua komponen kondisi fisik ini, latihan kelincahan (agility) merupakan salah satu latihan yang wajib diberikan kepada atlet. Karena cabang olahraga bola voli sangat membutuhkan kelincahan yang baik untuk merubah posisi tubuh dengan kecepatan yang tinggi. Bisa dilihat dari hasil kejuaraan nasional bola voli indoor yang diadakan di Universitas Negeri Jakarta, hasil yang diperoleh tim Fortius Universitas Negeri Jakarta tidak maksimal dikarenakan ada beberapa faktor kondisi fisik yang tidak dimiliki atlet dengan baik salah satunya adalah kelincahan. Dimana ketika seorang atlet bola voli tidak memiliki kelincahan yang baik, maka atlet akan kesulitan dalam melakukan gerakan teknik yang membutuhkan kelincahan seperti block dan defense spike.

Komponen tehnik defense dan block sangat membutuhkan kelincahan yang baik dari seorang atlet, dikarenakan ketika melakukan block dan defense, kita harus merubah arah gerakan kita dengan kecepatan yang maksimal terhadap rangsangan bola. Dikarenakan serangan dari lawan tidak dapat diprediksi oleh atlet. Kelincahan itu dapat ditingkatkan dengan menggunakan beberapa metode latihan antara lain dengan menggunakan metode latihan cone dan metode latihan reaction ball.

Metode latihan cone merupakan suatu bentuk latihan yang menjadikan kerucut atau cone sebagai batas dan rintangan pada saat melakukan suatu gerakan dengan tujuan untuk meningkatkan kelincahan. Metode latihan reaction ball merupakan metode latihan yang, menggunakan bola yang terdapat 6 sisi dimana ketika bola itu dilempar, pantulan yang dihasilkan akan memantul secara acak dan tidak dapat diprediksi arah bola tersebut akan memantul kemana. Metode latihan reaction ball tersebut dapat meningkatkan kelincahan, koordinasi mata-tangan dan reaksi.

Hal ini mendorong untuk melakukan penelitian agar dapat mengetahui cara meningkatkan kelincahan para atlet bola voli, dengan memberikan beberapa metode latihan kelincahan yang berbeda, yaitu menggunakan cone dan reaction ball. Sehingga kita dapat 
mengetahui sejauh mana peningkatan kemampuan kelincahan atlet puteri bola voli Fortius Universitas Negeri Jakarta dengan menggunakan dua metode latihan yang diberikan tersebut.

\section{LATIHAN}

Pada setiap cabang olahraga yang digeluti oleh seorang atlet, baik itu yang amatir maupun profesional, target utama yang ingin dicapai tentunya adalah prestasi. Namun, sebuah prestasi tidak akan dapat diraih tanpa adanya proses latihan.

Latihan berasal dari kata dalam bahasa Inggris yang mengandung dalam beberapa makna seperti: practice, exercise, training. Latihan adalah proses yang sistematis dari pada berlatih atau bekerja secara berulangulang, dengan kian hari kian menambah jumlah atau volume latihan. Latihan juga merupakan aktifitas olahraga yang sistematis dalam waktu yang lama ditingkatkan secara progresif dan individual yang mengarah kepada ciri-ciri fisiologis, dan psikologi manusia untuk mencapai sasaran yang telah ditentukan.

Dalam latihan juga terdapat prinsipprinsip, yang mana prinsip latihan ini harus dimengerti dan diterapkan. Untuk merancang program latihan, pelatih harus memahami karakteristik perkembangan prestasi dan respon atlet terhadap program latihan yang diberikan. Berkenaan dengan itu pelatih harus menguasai prinsip-prinsip latihan yang dapat digunakan pedoman melatih. Menurut Dw Hatmasari, dkk. Prinsip-prinsip latihan sebagai berikut:

1. Partisipasi aktif

2. Multilateral

3. individual

4. Overload

5. Spesifikasi

6. Reversibility

7. Variasi Latihan

8. Periodisasi

\section{Program Latihan}

1) Program Jangka Panjang

a) Tahap dasar (Pembinaan Multilateral) pada usia 8-14 tahun yang dilakukan di sekolah dalam pendidikan jasmani. Melalui kegembiraan, pengembangan jasmani, rohani dan sosial. Kompetisi yang dapat diikuti adalah festival.

b) Tahap lanjutan (Spesialisasi)

1. Usia 15-17 tahun. Dilakukan disekolah melalui pendidikan jasmani serta klub olahraga. Ditahap ini merupakan awal latihan pada cabang olahraga pilihan. Kompetisi yang dapat diikuti adalah antar sekolah.

2. Usia 18-20 tahun. Dilakukan disekolah (perguruan tinggi) serta di klub olahraga, Pengprov, dan Pengurus Besar cabang olahraga yang ditekuni. Ditahap ini merupakan akhir latihan pada cabang olahraga khusus. Kompetisi yang dapat diikuti antara lain kompetisi tingkat daerah dan Nasional.

c) Tahap Prestasi Tertinggi, pada usia 21 tahun keatas. Ditahap ini merupakan latihan tingkat tinggi bagi atlet dengan kompetisi Internasional.

2) Program Jangka Menengah

a) Program yang dirancang pada setiap tahap latihan.

b) Tahapan ini menunjukan bagaimana proses latihan. Merupakan sistem yang jelas, dimana tahap yang lebih awal merupakan batu loncatan utuk menuju tahap selanjutnya.

3) Program Jangka Pendek / Program Tahunan

Program latihan tahunan (periodisasi) merupakan alat untuk mengarahkan latihan selama satu tahun. Periodisasi adalah pondasi dari program latihan seorang atlet. Dalam 
program latihan ini, menentukan peak performance. Untuk menentukan peak performance, dapat dilihat dari kalender kompetisi. Dengan melihat seberapa pentingnya kompetisi yang akan diikuti. Tidak jarang dalam satu tahun, terdapat lebih dari satu kompetisi yang ikuti, sehingga dalam satu tahun terdapat 1 sampai 3 peak performance didalam program tahunan.

Dari setiap program latihan, terdapat 3 fase latihan yaitu fase persiapan, fase pertandingan dan fase transisi. Fase-fase ini dirancang untuk menstimulasi adaptasi fisiologis dan psikologis dan secara bertahap membentuk komponen spesifik yang dibutuhkan (fisik, teknik, dan taktik) untuk meningkatkan prestasi seorang atlet untuk menghadapi pertandingan.

Jadi dapat disimpulkan bahwa latihan harus terprogram dan terarah agar terdapat peningkatan pada atlet dan atlet dapat menstimulasi adaptasi fisiologis mauoun psikologi.

\section{LATIHAN CONE}

Cone drill suatu bentuk latihan yang menjadikan kerucut atau cone sebagai batas dan rintangan pada saat melakukan suatu gerakan dengan tujuan untuk meningkatkan kelincahan. Tujuan dari setiap bagian ini adalah untuk meningkatkan gerakan melalui serangkaian perubahan arah yang direncanakan. Pelatih dapat juga mengganti model latihan ke semiopen dengan menciptakan gerakan pilihan dan memiliki atlet yang merespon stimulus eksternal. Jadi Cone alat yang berbentuk kerucut untuk melatih kelincahan. Biasa digunakan pelatih memberikan berbagai variasi program latihan untuk kelincahan dan berbagai model latihannya. Oleh karena itu.

Adapun contoh-contoh latihan untuk meningkatakan kelincahan menggunakan cone antara lain:
1) Square Drill (Variation: carioca, shuffle stepor hop on one foot)

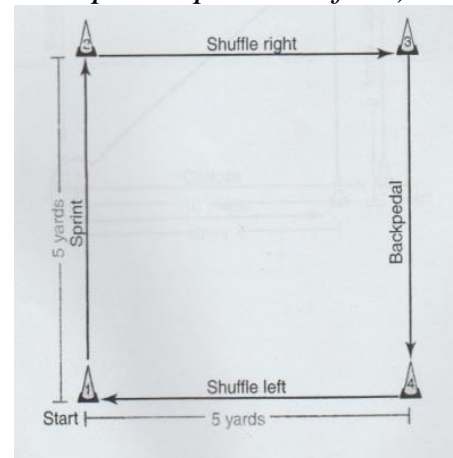

Gambar 1: Square drill

Sumber: Lee E. Brown dan Vance A. Ferrigno,

Training for Speed, Agility, Quickness, (USA: Human Kinetics, 2005)

1. Prosedur pelaksanaan:

1. Buatlah area persegi seperti pada gambar 1 dengan menggunakan cone. Setiap cone masing-masing berjarak 5 meter.

2. Seperti pada gambar 9. Start dimulai dari cone 1 sprint ke cone 2.

3. Dari cone 2 bergerak menyamping ke kanan menuju cone 3.

4. Dari cone 3 lalu kemudian mundur menuju cone 4.

5. Dari cone 4 menyamping ke kiri menuju cone 1.

2. Variasi

Untuk gerakan dari cone 2 ke cone 3 dan dari cone 4 ke cone 1 bisa diganti dengan gerakan carioca atau hop on one foot. 
2) Shuttle Run

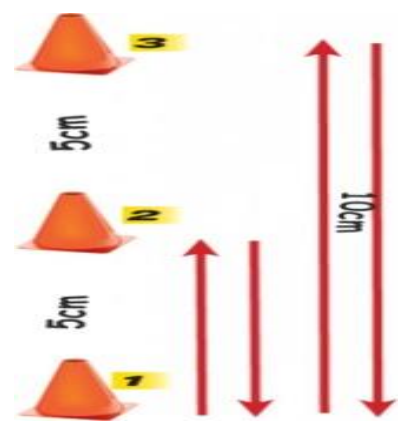

Gambar 2: shuttle run

Sumber:https://www.topendsports.blogspot.c om

(diakses pada tanggal 25 januari 2017)

a. Prosedur pelaksanaan :

1. Buatlah dan tempatkanlah cone seperti yang ditunjukan pada gambar 6. Jarak antara cone 1, 2, dan 3 masing-masing berjarak 5 meter.

2. Sprint dari cone 1 ke cone 2

3. Dari cone 2 sprint ke cone 1

4. Sprint dari cone 1 ke cone 3

5. Lalu dari cone 3 sprint ke cone 1.

3) 8 run

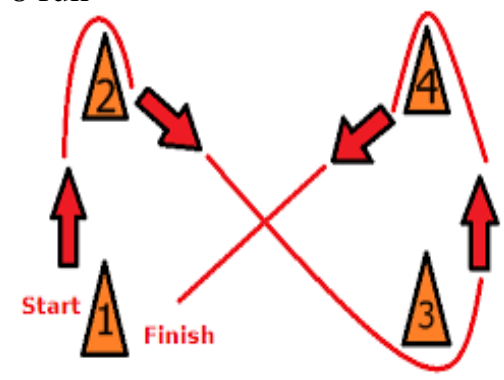

Gambar 3: 8run

Sumber:https://www.tsukinegradprogram.blo gspot.com

(diakses pada tanggal 25 januari 2017)

a. Prosedur pelaksanaan:

1. Buatlah dan tempatkanlah cone seperti yang ditunjukan pada gambar 7 .

2. Sprint dari cone 1 ke cone 2

3. Dari cone 2 sprint ke cone 3
4. Sprint dari cone 3 ke cone 4

5. Lalu dari cone 4 sprint ke cone 1

\section{LATIHAN REACTION BALL}

Reaction ball yaitu bola yang terdapat 6 sisi dan apabila di jatuhkan/pantulkan bola tersebut tidak menentu arah memantulnya. Reaction ball memiliki 3 macam ukuran yaitu kecil, sedang, dan besar. Berikut gambar reaction ball:

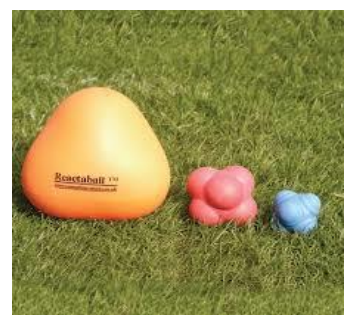

Gambar 4: Reaction ball

Sumber : https://www.spri.com

(Diakses pada tanggal 12 Februari 2017)

Pelatihan dengan menggunakan reaction ball dapat memberikan reaksi dan melakukan gerakan kesegala arah secara cepat. Jadi, peningkatan latihan dengan menggunakan bola tersebut dapat meningkatkan kelincahan, koordinasi matatangan dan reaksi.

Reaction ball digunakan untuk melatih kelincahan karena dengan bentuk yang terdapat 6 sisi tersebut maka atlet dapat bergerak dengan cepat untuk merubah gerak tubuh dan dapat melatih koordinasi. Latihan dengan menggunakan reaction ball sangat menarik dan dapat digunakan oleh semua jenjang usia, laki-laki maupun perempuan maka alat ini di rancang untuk melatih kelincahan, reaksi, dan koordinasi gerak tubuh.

Reaction ball dalam olahraga bola voli sangat membantu untuk konsentrasi, kelincahan, dan reaksi. Karena dalam bola voli bola datang tidak selalu di depan kita, 
maka dari itu reaction ball sangat membantu untuk melatih kelincahan.

Berikut cara melatih kelincahan dengan menggunakan reaction ball :

1. Bounce and Catch

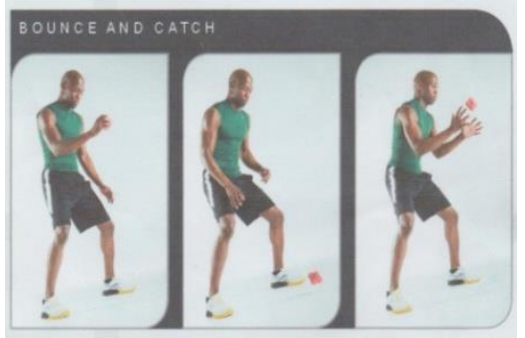

Gambar 5: Bounch and Catch

Sumber : https://www.spri.com

(Diakses pada tanggal 12 januari 2017)

a. Prosedur pelaksanaan

1. Bola dilempar dengan satu tangan kelantai didepan badan

2. Lalu biarkan memantul dilantai

3. Ketika sudah memantul ditangkap diantara tinggi pinggang dan bahu dan selanjutkan dapat dilakukan dengan satunya.

\section{Bounce, Spin, dan Catch}

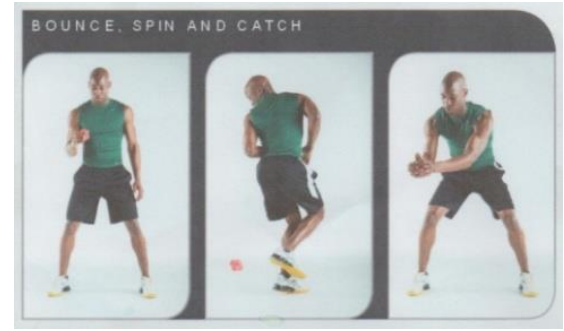

Gambar 6: Bounch, spin and Catch

Sumber : https://www.spri.com

(Diakses pada tanggal 12 Februari 2017)

a. Prosedur pelaksanaan

1. Bola dilempar dengan satu tangan kelantai didepan badan

2. Lalu berputar $360^{\circ}$

3. Ketika sudah berputar lalu menangkap bola tersebut.
3. Wall Toss and Catch

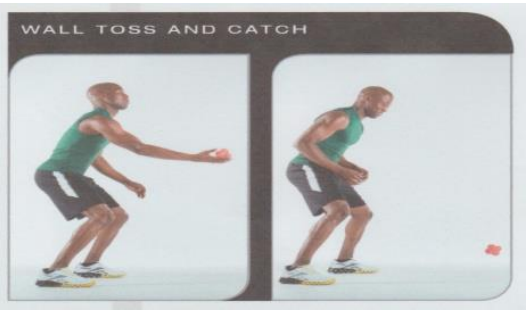

Gambar 7: Wall Toss And Catch

Sumber : https://www.spri.com

(Diakses pada tanggal 12 Februari 2017)

a. Prosedur pelaksanaan

1. Posisi badan menghadap dinding, lalu bola dilempar ke dinding setinggi antara bahu dan kepala

2. Lalu biarkan bola tersebut memantul kelantai

3. Ketika sudah memantul lalu tangkap bola tersebut selanjutnya dapat dilakukan dengan tangan satunya.

\section{Wall Roll and Catch}

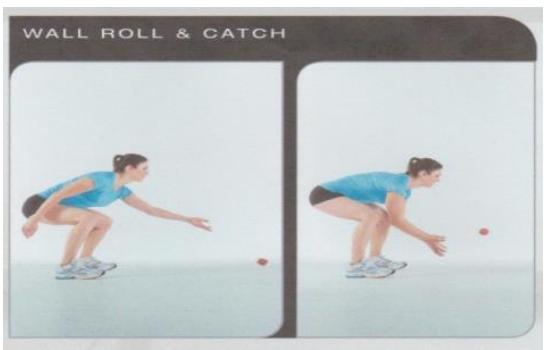

Gambar 8: Wall Roll and Catch

Sumber: https://www.spri.com

(Diakses pada tanggal 12 januari 2017)

a. Prosedur pelaksanaan

1. Posisi badan menghadap dinding, lalu bola digelindingkan didepan tubuh

2. Kemudian tangkap bola ketika bola memantul kembali dari dinding

3. Dan ulangi dengan tangan bergantian (berlawanan) 


\section{Partner Roll and Catch}

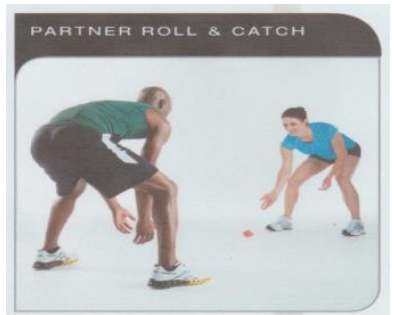

Gambar 9: Partner Roll and Catch

Sumber: https://www.spri.com

(Diakses pada tanggal 12 Februari 2017)

a. Prosedur pelaksanaan

1. Gulirkan langsung bola kelantai dari depan tubuh.

2. Kemudian pasangan menangkap bola dibawah antara pergelangan kaki dan lutut

3. Dan ulangi dengan pasangan menggulirkan bola kembali kearah berlawanan.

\section{Partner bounch and Catch}

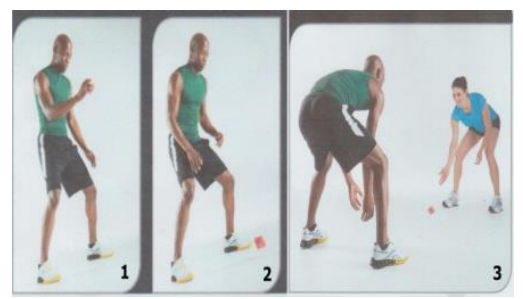

Gambar 10: Partner Bounch and Catch

Sumber: https://www.spri.com

(Diakses pada tanggal 12 Februari 2017)

a. Prosedur pelaksanaan

1. Pantulkan bola kelantai didepan tubuh dengan pasangan menangkap bola antara lutut dan bahu tinggi.

2. Kemudian ulangi dengan pasangan memantul bolanya kembali ke arah yang berlawanan.

Dari penjelasan diatas maka bola voli merupakan asiklis maka kelincahan perlu ditingkatkan. Kata lincah sendiri berarti bergerak merubah arah atau berputar secara cepat. Kelincahan merupakan kemampuan melakukan sebuah gerakan yang singkat atau cepat dalam waktu yang sesingkat mungkin. Kelincahan adalah kesinambungan antara perpaduan fleksibilitas kelenturan oleh tubuh dan kesinambungan otot-otot yang bekerja untuk menghasilkan gerak yang singkat dan komplek.

Kelincahan adalah seperangkat keterampilan kompleks yang dilakukan seseorang untuk merespon stimulus eksternal dengan perlambatan, perubahan arah dan reacceleration. Kelincahan adalah kemampuan untuk merubah arah dan posisi tubuh dengan cepat dalam keadaan bergerak, tanpa kehilangan keseimbangan. Dari beberapa pengertian di atas, yang menjadi karakteristik kelincahan, yaitu kecepatan dan ketepatan perubahan arah lari, perubahan posisi tubuh, dan perubahan arah bagianbagian tubuh (body movement).

Kelincahan dipengaruhi oleh berbagai faktor internal maupun eksternal. Faktor internal adalah faktor-faktor yang berasal dari dalam diri subjek sehingga dapat dikontrol oleh subjek. Sedangkan, faktor eksternal berasal dari luar diri subjek dan tidak dapat dikontrol sendiri oleh subjek. Dari penjelasan di atas adapun faktor yang mempengaruhi kelincahan seseorang yaitu:

a. Usia: menunjukan bahwa anak laki-laki rata-rata semakin bertambah baik mulai usia 12 tahun, sedang anak wanita tidak lagi bertambah baik setelah usia 13 tahun.

b. Jenis Kelamin: Anak pria memperlihatkan kelincahan yang lebih baik dari pada wanita sebelum mereka mencapai usia pubertas. Setelah pubertas perbedaan tersebut lebih mencolok.

c. Berat Badan: Berat badan yang berlebihan secara langsung akan mengurangi kelincahan. Dimana berat badan yang berlebihan cenderung mengakibatkan muscle imbalance di bagian trunk.

d. Kelelahan: Kelelahan dapat mempengaruhi kelincahan, karena orang 
yang lelah akan menurun kecepatan lari dan koordinasinya.

Atlet yang memiliki kelincahan yang baik dapat menghasilkan gerak yang efektif. Kegunaan secara langsung kelicahan untuk:

a. Mengkoordinasikan gerak-gerak berganda.

b. Mempermudah berlatih teknik tinggi.

c. Gerakan dapat efisien dan efektif.

d. Mempermudah daya orientasi dan antisipasi terhadap setiap gerakan lawan.

e. Menghindari terjadinya cidera.

Berbagai pendapat tersebut kelincahan dapat disimpulkan sebagai suatu kemampuan gerak individu untuk merubah posisi dan arah gerak secara cepat dan tepat dalam situasi yang dihadapi dan dikehendaki dengan melibatkan unsur fisik yang lain mendukung proses tersebut, dalam hal ini kelincahan terkait dengan bola voli yaitu kemampuan untuk merubah arah gerak secara cepat dalam melakukan block dan defense. Hal ini dapat terlihat pada saat seorang pemain mampu membendung serangan dari lawan dan pergerakan apabila bola yang tidak terduga, baik saat pemain sedang melakukan serangan maupun pertahanan.

\section{KERANGKA BERPIKIR}

Metode latihan cone dapat meningkatkan kelincahan.

Latihan cone merupakan latihan dengan menggunakan alat yang berbentuk kerucut. Latihan cone sebagai batas dan rintangan pada saat melakukan suatu gerakan. Dalam meningkatkan kemampuan kelincahan pada suatu cabang olahraga yang membutuhkan kelincahan ialah menggunakan salah satu metode latihan seperti yang dibahas adalah latihan cone. Dengan latihan cone seorang atlet melakukan gerakan untuk melewati cone yang telah dibentuk formasinya, karena latihan cone dapat divariasikan sesuai kebutuhan yang diperlukan dicabang bola voli. Pelatih juga dapat mengganti model latihan ke semiopen dengan menciptakan gerakan pilihan dan memiliki atlet yang merespon stimulus eksternal. Latihan cone bertujuan untuk meningkatkan kelincahan seorang atlet.

Metode latihan reaction ball dapat meningkatkan kelincahan.

Latihan reaction ball merupakan latihan dengan menggunakan bola yang terdapat 6 sisi. Dengan bentuk bola yang terdapat 6 sisi tersebut apabila bola dijatuhkan atau dipantulkan bola tersebut tidak menentu arah memantulnya dan ketika latihan ini diberikan pada materi latihan kelincahan seorang atlet yang diberikan latihan dengan menggunakan alat ini berusaha untuk menangkap bola dengan arah pantulan yang tidak menentu tersebut. Karena dengan hasil pantulan yang tidak menentu itu seorang atlet harus menggunakan kelincahannya untuk menangkap bola tersebut. Latihan Reaction ball bertujuan untuk meningkatkan kelincahan.

Metode latihan cone lebih baik dibandingkan dengan metode reaction ball terhadap kelincahan.

Dari kedua metode latihan yang telah dijelaskan bahwa pada prinsipnya sama yaitu meningkatkan kelincahan. Dengan dibantu menggunakan alat dalam meningkatkan kelincahan ini merupakan salah satu metode yang dipilih oleh setiap pelatih. Dari kedua metode latihan yang dibahas peneliti beranggapan bahwa metode latihan cone lebih efektif dibandingkan metode latihan reaction ball, Karena dengan metode latihan Cone yang banyak variasi formasinya akan lebih dapat meningkatkan dengan baik dan memberikan sebuah variasi latihan kepada 
atlet agar tidak monoton dibandingkan dengan metode latihan Reaction ball karena metode latihan ini lebih menyulitkan atlet karena hasil pantulan bola yang tidak terarah ini membuat atlet kaget dan terburu-buru untuk menangkap bola sehingga kurang efektif dan harus lebih fokus untuk melatih kelincahannya.

\section{PENGAJUAN HIPOTESIS}

Berdasarkan perumusan masalah, kerangka teoritis dan kerangka berfikir, maka penelitian mengajukan hipotesis antara lain:

1. Metode latihan cone dapat meningkatan kelincahan dengan pada atlet puteri klub Fortius Universitas Negeri Jakarta.

2. Metode latihan cone dapat meningkatan kelincahan dengan pada atlet puteri klub Fortius Universitas Negeri Jakarta.

3. Terdapat Perbedaan metode latihan cone dengan metode latihan reaction ball terhadap kelincahan pada atlet klub bola voli puteri Fortius Universitas Negeri Jakarta.

\section{METODE PENELITIAN}

Metode yang digunakan dalam penelitian ini adalah metode eksperimen. Penelitian eksperimen adalah suatu penelitian dimana peneliti sengaja membuat suatu kejadian atau keadaan timbul, lalu meneliti akibatnya.

Adapun untuk mengetahui variabel bebas dan variabel terikat dalam penelitian ini yaitu:

a. Variabel bebas: metode latihan cone dan reaction ball

b. Variabel terikat: kelincahan pada atlet puteri klub bola voli Fortius Universitas Negeri Jakarta.

Penelitian diawali dengan tes awal untuk mengetahui sejauh mana kelincahan atlet bola voli puteri Universitas Negeri Jakarta. kemudian diberikan perlakuan latihan yang berbeda dan dilakukan tes akhir untuk mengetahui sejauh mana tingkat perkembangan kelincahan atlet bola voli puteri ini setelah diberikan metode latihan cone dan reaction ball.

Pola yang digunakan sebagai berikut:

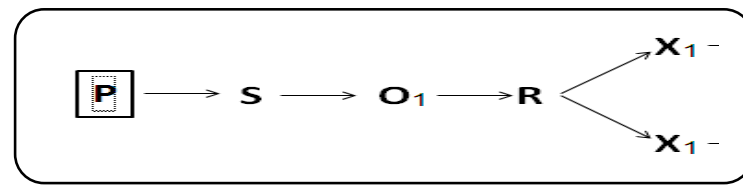

Keterangan:

$\begin{array}{ll}\mathrm{P} & \text { : Populasi } \\ \mathrm{S} & \text { : Sampel } \\ \mathrm{O}_{1} & \text { : Tes awal } \\ \mathrm{R} & \text { : Ranking } \\ \mathrm{X}_{1} & \text { : Latihan cone } \\ \mathrm{Y}_{1} & \text { : Latihan reaction ball } \\ \mathrm{O}_{2} & \text { : Tes akhir }\end{array}$

\section{POPULASI DAN SAMPEL}

\section{Populasi Penelitian}

Populasi adalah wilayah generasi yan terdiri: subjek atau objek dengan kualitas dan karakter tertentu yang ditetapkan oleh peneliti untuk dipelajari dan kemudian ditarik kesimpulan. Populasi dalam penelitian ini adalah atlet Klub bola voli Fortius Universitas Negeri Jakarta yang terdiri dari 45 atlet putra dan 27 orang atlet puteri.

\section{Teknik Pengambilan Sampel}

Sampel adalah bagian dari jumlah dan karakteristik yang dimiliki oleh populasi tersebut. Sampel yang digunakan dalam penelitian ini adalah purposive sampling. Dengan demikian tidak semua anggota puteri masuk didalam sampel karena sampel karena sampel yang dapat diambil harus memiliki beberapa kriteria sebagai berikut:

a. Atlet puteri klub bola voli Fortius Universitas Negeri Jakarta

b. Anggota aktif klub bola voli Fortius Universitas Negeri Jakarta 
c. Atlet puteri klub bola voli Fortius Universitas Negeri Jakarta usia 18-25 tahun.

d. Bersedia mengikuti program latihan akan diberikan selama 16 kali pertemuan.

Sehingga sampel yang memenuhi kriteria diatas berjumlah 20 orang atlet puteri klub bola voli Fortius Universitas Negeri Jakarta.

3. Teknik Pengambilan Data

Teknik pengambilan data yang dilakukan dalam penelitian ini adalah:

a. Seluruh sampel melakukan tes awal pada tanggal 6 Maret 2017.

b. Dari data hasil tes awal yang didapat, diurutkan rangking berurutan berdasarkan dari hasil tertinggi sampai ke yang terendah.

c. Kemudian membagi menjadi dua kelompok berdasarkan urutan yang diperoleh berdasarkan urutan rangkingnya (kelompok ganjil \& kelompok genap).

Kelompok A (Ganjil):
$1,3,5,7,9,11,13,15,17,19$

Kelompok B

2,4,6,8,10,12,14,16,18,20

(Genap):

d. Kemudian melakukan undian untuk menentukan pelaksanaan metode latihan yang akan diberikan:

Kelompok ganjil: Metode latihan cone.

Kelompok genap: Metode latihan reaction ball.

\section{INSTRUMEN PENELITIAN}

Instrumen penelitian adalah alat atau fasilitas yang digunakan oleh penelitian dalam mengumpulkan data agar pekerjaannya lebih mudah dan hasilnya lebih baik, dalam arti lebih cermat, lengkap dan sistematis sehingga lebih mudah diolah. Instrument tes yang digunkan dalam penilitian ini adalah $T$ Run Agility Test dengan ketentuan sebagai berikut:

a. Pelaksanaan Tes
1) Subjek berdiri dari garis start A. Ketika ada aba-aba dari pencatat waktu,

2) subjek mulai berlari dari garis start A menuju ke titik B dengan menyentuhkan tangan kanannya pada kerucut B

3) kemudian dari kerucut B berlari kearah titik $\mathrm{C}$ dan menyentuhkan kerucut dengan tangan kiri

4) setelah itu berlari kearah $D$ dan menyentuhkan kerucutnya dengan tangan yang kanan.

5) Kembali ketitik B dengan menyentuhkan kerucut dengan tangan kiri.

6) Kemudian menuju garis finish (titik A) dan stopwatch dihentikan setelah subjek melewati kerucut A.

b. Cara penilaian

1) Pengetesan dianggap gagal jika tangan tidak menyentuh dasar kerucut, atau kerucutnya terseret. Waktu dicatat sampai 0,1 detik

2) Subjek dikasih 1 kesempatan melakukan Agility T-Test

c. Alat/fasilitas yang diperlukan

1) Stopwatch

2) Lintasan lari datar panjang minimal 10meter dan lebar 10 meter

3) Pluit

4) Alat tulis

5) Kamera

\section{HASIL PENELITIAN}

1) Data Tes Awal Kelincahan Menggunakan Metode Latihan Cone

Dari hasil tes awal dan perhitungan variabel latihan dengan menggunakan cone, dapat diperoleh nilai rata-rata $\left(\mathrm{x}_{1}\right)$ sebesar 11,82 simpangan baku $\left(\mathrm{Sx}_{1}\right)$ sebesar 0,75 dan standar kesalahan mean $\left(\mathrm{SEmx}_{1}\right)=0,25$. Distribusi Frekuensi dapat dilihat pada tabel di bawah ini.

Tabel 1. Distribusi Frekuensi Tes Awal Kelincahan Menggunakan Metode Latihan Cone 


\begin{tabular}{|c|c|c|c|c|}
\hline \multirow{2}{*}{ NO } & \multirow{2}{*}{ Kelas Interval } & \multicolumn{3}{|c|}{ Frekuensi } \\
\cline { 3 - 5 } & & Absolut & Relatif (\%) & Kumulatif (\%) \\
\hline 1 & $10.47 \cdot 10.97$ & 1 & 10 & 10 \\
\hline 2 & $10.98 \cdot 11.48$ & 3 & 30 & 40 \\
\hline 3 & $11.49 \cdot 11.99$ & 3 & 30 & 70 \\
\hline 4 & $12.00 \cdot 12.50$ & 2 & 20 & 90 \\
\hline 5 & $12.51 \cdot 13.01$ & 1 & 10 & 100 \\
\hline \multicolumn{2}{|c|}{ JUMLAH } & 10 & 100 & \\
\hline
\end{tabular}

Berdasarkan data dari tabel di atas tes awal latihan dengan menggunakan metode latihan cone, terlihat atlet Puteri bola voli Fortius Universitas Negeri Jakarta 10.98 - 11.48 dan 11.49 - 11.99 dengan presentase $70 \%$ dan frekuensi terkecil terdapat pada interval 10.47 - 10.97 dan 12.51 - 13.01 dengan presentasi $10 \%$ Selanjutnya histogram tes awal latihan dengan menggunakan metode latihan cone dapat dilihat pada gambar di bawah ini :

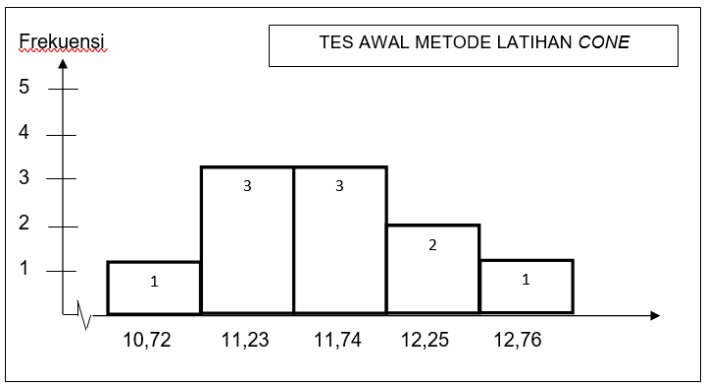

Gambar 16. Grafik Histogram Data Tes Awal Kelincahan Dengan Menggunakan Metode Latihan Cone

1) Data Tes Akhir Kelincahan Dengan Menggunakan Metode Latihan Cone

Dari hasil tes akhir dan perhitungan variabel Latihan dengan menggunakan metode latihan cone, dapat diperoleh nilai rata-rata sebesar 9,86 $\left(\mathrm{x}_{1}\right)$ simpangan baku $\left(\mathrm{Sx}_{1}\right)$ sebesar 0,32 dan dan standar kesalahan mean $\left(\mathrm{SEmx}_{1}\right)=$ 0,11. Distribusi Frekuensi dapat dilihat pada tabel di bawah ini.
Tabel 2. Distribusi Frekuensi Tes Akhir Kelincahan Dengan Menggunakan Metode Latihan Cone.

\begin{tabular}{|c|c|c|c|c|}
\hline \multirow{2}{*}{ NO } & \multirow{2}{*}{ Kelas Interval } & \multicolumn{3}{|c|}{ Frekuensi } \\
\cline { 3 - 5 } & & Absolut & Relatif (\%) & Kumulatif (\%) \\
\hline 1 & $9.31-9.54$ & 1 & 10 & 10 \\
\hline 2 & $9.55-9.78$ & 2 & 20 & 30 \\
\hline 3 & $9.79-10.02$ & 4 & 40 & 70 \\
\hline 4 & $10.03-10.26$ & 2 & 20 & 90 \\
\hline 5 & $10.27-10.50$ & 1 & 10 & 100 \\
\hline \multicolumn{2}{|c|}{ JUMLAH } & 10 & & \\
\hline
\end{tabular}

Berdasarkan data dari tabel di atas tes akhir latihan dengan menggunakan metode latihan cone, terlihat atlet Puteri bola voli Fortius Universitas Negeri Jakarta yang terdapat pada interval 9.79 - 10.02 dengan presentase $70 \%$ dan frekuensi terkecil terdapat pada interval 9.31 - 9.54 dan 10.27 - 10.50 dengan presentasi $10 \%$. Selanjutnya histogram tes akhir latihan dengan menggunakan metode latihan cone dapat dilihat pada gambar di bawah ini :

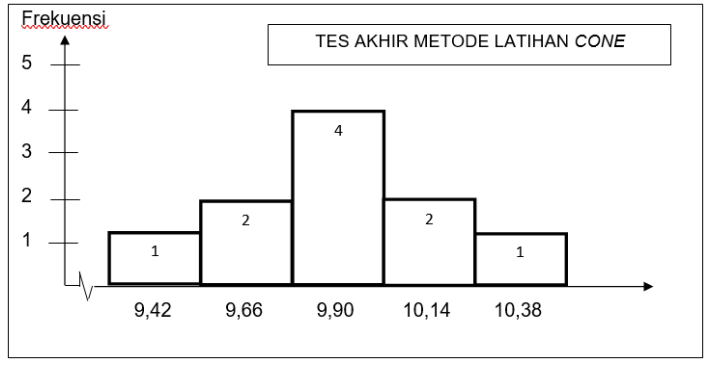

Gambar 17. Grafik Histogram Data Tes Akhir Kelincahan Dengan Menggunakan Metode Latihan Cone.

\section{Data Hasil Tes Kelincahan Dengan Menggunakan Metode Latihan Reaction ball}

1) Data Tes Awal Kelincahan Dengan Menggunakan Metode Latihan Reaction ball 
Dari hasil tes awal dan perhitungan variabel latihan dengan menggunakan reaction ball, rata-rata $\left(\mathrm{x}_{1}\right)$ sebesar 11,88 simpangan baku $\left(\mathrm{Sx}_{1}\right)$ sebesar 0,79 dan standar kesalahan mean $\left(\mathrm{SEmx}_{1}\right)=0,22$. Distribusi Frekuensi dapat dilihat pada tabel di bawah ini.

Tabel 3. Distribusi Frekuensi Tes Awal Kelincahan Dengan Menggunakan Metode Latihan Reaction ball

\begin{tabular}{|c|c|c|c|c|}
\hline \multirow{2}{*}{ NO } & \multirow{2}{*}{ Kelas Interval } & \multicolumn{3}{|c|}{ Frekuensi } \\
\cline { 3 - 5 } & & Absolut & Relatif (\%) & Kumulatif (\%) \\
\hline 1 & $10.97-11.41$ & 1 & 10 & 10 \\
\hline 2 & $11.42-11.86$ & 2 & 20 & 30 \\
\hline 3 & $11.87-12.31$ & 3 & 30 & 60 \\
\hline 4 & $12.32-12.76$ & 3 & 30 & 90 \\
\hline 5 & $12.77-13.21$ & 1 & 10 & 100 \\
\hline \multicolumn{2}{|c|}{ JUMLAH } & 10 & 100 & \\
\hline
\end{tabular}

Berdasarkan data dari tabel di atas tes awal latihan dengan menggunakan reaction ball, terlihat atlet puteri bola voli Fortius Universitas Negeri Jakarta frekuensi terbesar terdapat pada interval $11.87-12.31$ dan 12.32 - 12.76 dengan presentase $60 \%$ dan frekuensi terkecil terdapat pada interval $10.97-11.41$ dan 12.77 - 13.21 dengan presentasi 10\%. Selanjutnya histogram tes awal dengan menggunakan metode latihan reaction ball dapat dilihat pada gambar di bawah ini :

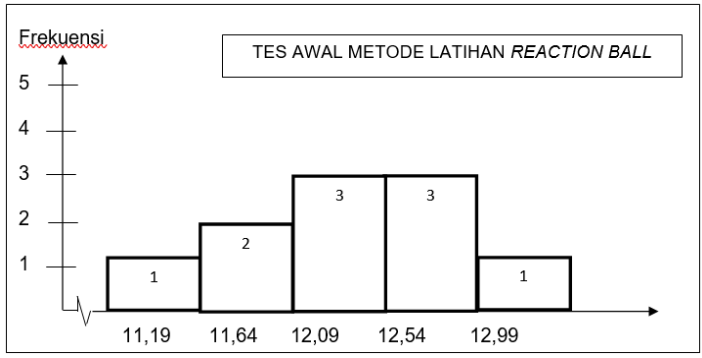

Gambar 18. Grafik Histogram Data Tes Awal Kelincahan Dengan Menggunakan Metode Latihan Reaction ball
Data Tes Akhir Kelincahan Dengan Menggunakan Metode Latihan Reaction ball Dari hasil tes awal dan perhitungan variabel latihan dengan menggunakan reaction ball, rata-rata $\left(\mathrm{x}_{1}\right)$ sebesar 10,40 simpangan baku $\left(\mathrm{Sx}_{1}\right)$ sebesar 0,48 dan standar kesalahan mean $\left(\mathrm{SEmx}_{1}\right)=0,16$. Distribusi Frekuensi dapat dilihat pada tabel di bawah ini.

Tabel 4. Distribusi Frekuensi Tes Akhir Kelinvahan Dengan Menggunakan Metode Latihan Reaction ball

\begin{tabular}{|c|c|c|c|c|}
\hline \multirow{2}{*}{ NO } & \multirow{2}{*}{ Kelas Interval } & \multicolumn{3}{|c|}{ Frekuensi } \\
\cline { 3 - 5 } & & Absolut & Relatif (\%) & Kumulatif (\%) \\
\hline 1 & $9.61-9.95$ & 2 & 20 & 20 \\
\hline 2 & $9.96-10.30$ & 2 & 20 & 40 \\
\hline 3 & $10.31-10.65$ & 3 & 30 & 70 \\
\hline 4 & $10.66-11.00$ & 2 & 20 & 90 \\
\hline 5 & $11.01-11.35$ & 1 & 10 & 100 \\
\hline \multicolumn{2}{|c|}{ JUMLAH } & 10 & 100 & \\
\hline
\end{tabular}

Berdasarkan data dari tabel di atas dibandingkan dengan nilai rata-rata tes awal latihan dengan menggunakan reaction ball, terlihat atlet puteri bola voli Fortius Universitas Negeri Jakarta bahwa frekuensi terbesar terdapat pada interval $10.31-10.65$ dengan presentase $70 \%$ dan frekuensi terkecil terdapat pada interval 11.01 - 11.35 dengan presentasi $10 \%$. Selanjutnya histogram tes awal dengan menggunakan metode latihan reaction ball dapat dilihat pada gambar di bawah ini:

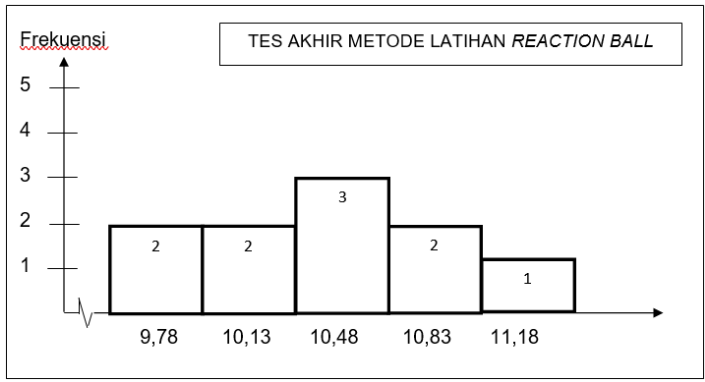

Gambar 19. Grafik Histogram Data Tes Akhir Kelincahan Dengan Menggunakan Metode Latihan Reaction ball 


\section{PENGUJIAN HIPOTESIS}

Hipotesis penelitian ini terdiri dari 3 pernyataan hipotesis. Uji hipotesis menggunakan uji t, yang dijelaskan sebagai berikut:

1. Terdapat Peningkatan kelincahan pada atlet puteri klub bola voli Fortius Universitas Negeri Jakarta setelah diberikan metode latihan cone.

Hasil analisis dari tes awal dan tes akhir hasil kelincahan pada atlet puteri klub bola voli Fortius Universitas Negeri Jakarta dengan menggunakan metode latihan cone diperoleh nilai rata-rata deviasi $\left(\mathrm{M}_{\mathrm{D}}\right)=1,96$ dan simpangan baku $\left(\mathrm{S}_{\mathrm{D}}\right)=0,53$. Hasil tersebut menghasilkan $t_{\text {tabel }}$ pada derajat kebebasan $(\mathrm{dk})=\mathrm{n}-1=10-1=9$ dengan taraf kepercayaan $(\alpha)=0,05$ diperoleh nilai kritis $t_{\text {tabel }}=2,262$. Dengan demikian nilai $\mathrm{t}_{\text {hitung }}$ lebih besar dari $\mathrm{t}_{\text {tabel }}\left(\mathrm{t}_{\text {hitung }}=10,888>\right.$ $\mathrm{t}_{\text {tabel }}=2,262$ ).

Berdasarkan hipotesis statistik untuk peningkatan kelincahan pada atlet puteri klub bola voli Fortius Universitas Negeri Jakarta yaitu hipotesis nol $\left(\mathrm{H}_{0}\right)$ ditolak. Hasil perhitungan diperoleh $t_{\text {hitung }}$ sebesar 10,888 dan $t_{\text {tabel }}$ sebesar 2,262 dengan taraf signifikan $\alpha=0,05$. Dengan demikian $t_{\text {hitung }}>t_{\text {tabel }}$ maka hipotesis nol $\left(\mathrm{H}_{0}\right)$ ditolak, hipotesis kerja $\left(\mathrm{H}_{1}\right)$ diterima, sehingga dapat disimpulkan bahwa terdapat peningkatan kelincahan pada atlet puteri klub bola voli Fortius Universitas Negeri Jakarta setelah diberikan metode latihan cone.

2. Terdapat Peningkatan kelincahan pada atlet puteri klub bola voli Fortius Universitas Negeri Jakarta setelah diberikan metode latihan reaction ball.

Hasil analisis dari tes awal dan tes akhir hasil kelincahan pada atlet puteri klub bola voli Fortius Universitas Negeri Jakarta dengan menggunakan metode latihan reaction ball diperoleh nilai rata-rata deviasi $\left(\mathrm{M}_{\mathrm{D}}\right)=1,64$ dan simpangan baku $\left(\mathrm{S}_{\mathrm{D}}\right)=0,52$. Hasil tersebut menghasilkan $t_{\text {tabel }}$ pada derajat kebebasan $(\mathrm{dk})=\mathrm{n}-1=10-1=9$ dengan taraf kepercayaan $(\alpha)=0,05$ diperoleh nilai kritis $t_{\text {tabel }}=2,262$. Dengan demikian nilai $t_{\text {hitung }}$ lebih besar dari $t_{\text {tabel }}\left(t_{\text {hitung }}=9,647>\right.$ $t_{\text {tabel }}=2,262$ ).

Berdasarkan hipotesis statistik untuk peningkatan kelincahan pada atlet puteri klub bola voli Fortius Universitas Negeri Jakarta yaitu hipotesis nol $\left(\mathrm{H}_{0}\right)$ ditolak. Hasil perhitungan diperoleh $t_{\text {hitung }}$ sebesar 9,647 dan $\mathrm{t}_{\text {tabel }}$ sebesar 2,262 dengan taraf signifikan $\alpha=$ 0,05 . Dengan demikian $t_{\text {hitung }}>t_{\text {tabel }}$ maka hipotesis nol $\left(\mathrm{H}_{0}\right)$ ditolak, hipotesis kerja $\left(\mathrm{H}_{1}\right)$ diterima, sehingga dapat disimpulkan bahwa terdapat peningkatan kelincahan pada atlet puteri klub bola voli Fortius Universitas Negeri Jakarta setelah diberikan metode latihan reaction ball.

3. Metode Latihan Cone Lebih Efektif Dibandingkan Dengan Reaction ball Dalam Meningkatkan Kelincahan Pada Atlet Puteri Klub Bola Voli Fortius Universitas Negeri Jakarta

Data tes akhir kelincahan pada atlet puteri klub bola voli fortius Universitas Negeri Jakarta pada kelompok metode latihan cone dengan kelompok latihan reaction ball diperoleh $t_{\text {hitung }}$ sebesar $=2,812$. Kemudian hasil perhitungan tersebut diujikan dengan tabel pada derajat kebebasan $(\mathrm{dk})=\left(\mathrm{n}_{1}+\mathrm{n}_{2}\right)$ $-2=18$ dan taraf kepercayaan $(\alpha)=0,05$ diperoleh nilai kritis $t_{\text {tabel }} 2,101$ ( $t_{\text {hitung }}=2,812$ $>t_{\text {tabel }}=2,101$ )

Berdasarkan hasil analisa data tersebut maka $\mathrm{H}_{0}$ ditolak dan $\mathrm{H}_{1}$ diterima sehingga dapat disimpulkan bahwa kelompok metode latihan cone lebih efektif dari pada kelompok metode latihan reaction ball terhadap peningkatan kelincahan pada atlet puteri klub bola voli fortius Universitas Negeri Jakarta. 


\section{KESIMPULAN}

Dari hasil penelitian, data yang diperoleh dengan perhitungan statisik, dapat disimpulkan bahwa:

1. Metode latihan dengan cone dapat meningkatkan kelincahan pada atlet puteri klub bola voli Fortius Universitas Negeri Jakarta.

2. Metode latihan dengan reaction ball dapat meningkatkan kelincahan pada atlet puteri klub bola voli Fortius Universitas Negeri Jakarta.

3. Metode latihan dengan cone lebih baik untuk meningkatkan kelincahan dibandingkan metode latihan dengan reaction Ball pada atlet puteri klub bola voli Fortius Universitas Negeri Jakarta.

\section{SARAN}

Berdasarkan hasil penelitian ini khususnya peningkatan kelincahan, maka beberapa saran dapat diajukan sebagai berikut:

1. Kepada atlet dan pelatih dapat menggunakan metode latihan cone sebagai salah satu metode latihan untuk meningkatkan kelincahan. Karena setelah dilakukan penelitian metode latihan cone signifikan dapat meningkatkan kelincahan pada atlet puteri klub bola voli Fortius Universitas Negeri Jakarta.

2. Meningkatkan kelincahan sangat penting, khususnya pada cabang olahraga bola voli yang setiap teknik dalam permainan memerlukan kelincahan yang maksimal.

3. Untuk yang melakukan penelitian serupa agar memperhatikan keseriusan atlet dalam menjalankan program karena latihan ini sangat penting dalam olahraga bola voli.

\section{DAFTAR PUSTAKA}

Anas Sudjiono, Pengantar Statistik Pendidikan, Jakarta: PT Raja Grafindo Persada, 2010

Bompa, Tdor O, Periodization Training for Sport, USA: Human Kinetics, 2005

Bompa, Tudor O, Theory and Methodology of Training, Human Kinetics, 1999

Dwi Hatmasari Ambarukmi, dkk, Pelatihan Pelatih Fisik, Jakarta: Kementrian Negara Pemuda Dan Olahraga, 2007.

Etta Mamang Sangadji dan Sopiah, Metodelogi penelitian, Malang: CV. Andi Offset, 2010.

Harsono, Ilmu Coaching, Pusat Ilmu Olahraga, KONI Pusat.

Jay Dawes dan Mark Roozen, Developing Agility and Quickness, Europe: Human Kinetics.

Lubis Johansyah, Panduan Praktis Penyusunan Program Latihan, Jakarta: Rajawali Pers, 2003.

Lee E. Brown dan Vance A. Ferrigno, Training for speed, agility, and quickness, USA: Human Kinetics, 2005.

Mansur, dkk, Pelatihan pelatih fisik level II, Jakarta: Kementrian Negara Pemuda Dan Olahraga, 2009.

Soewarno, Gerakan Dasar dan Teknik Dasar, Yogyakarta: PKO FIK UNY, 2001

Suharno, Ilmu Coaching Umum, Yogyakarta: Yayasan Sekolah Tinggi Indonesia, 2003

Sugiyono, Metode Penelitian Kuantitatif kualitatif dan $R \& D$ Bandung: Alfabeta, 2011

,Statistika Untuk Penelitian, Bandung : ALFABETA, 2015

Sukadiyanto \& Dangsina, Pengantar Teori Dan Metodelogi Melatih Fisik Bandung: CV. Lubuk Agung, 2011

Widiastuti, Tes dan Pengukuran Olahraga, Jakarta: PT Bumi Timur Jaya, 2011. 